\title{
Prey preference and niche overlap of ringed seals Phoca hispida and harp seals $P$. groenlandica in the Barents Sea
}

\author{
J. A. Wathne', T. Haug ${ }^{2}$, C. Lydersen ${ }^{3, *}$ \\ ${ }^{1}$ Norwegian Fishery College, University of Tromsø, 9037 Tromsø, Norway \\ ${ }^{2}$ Norwegian Institute of Fisheries and Aquaculture, Breivika, PO Box 2511, 9002 Tromse, Norway \\ ${ }^{3}$ Norwegian Polar Institute, 9296 Tromsø, Norway
}

\begin{abstract}
Ringed seals Phoca hispida and harp seals $P$. groenlandica were collected for diet analysis along the ice edge in the Barents Sea to investigate possible niche overlap between these 2 seal species. The diet analysis is based on contents from stomachs and intestines. A resource availability survey was conducted concurrently based on an echo survey combined with demersal and pelagic trawling. This survey showed that the potential prey biomass was dominated by pelagic crustaceans $(99 \%$ of total biomass) - principally Themisto libellula and Thyssanoessa spp. Despite the prevalence of these crustaceans both seal species showed a strong preference for fish of various species, which constituted only $1 \%$ of the biomass in the area. The most common fish in their diet was polar cod Boreogadus saida, which had a Manly's prey preference index of 0.87 for ringed seals and 0.42 for harp seals. Pianka's niche overlap index for the 2 seal species in this area was 0.985 , indicating an almost complete niche overlap. However, harp seals prey on significantly larger polar cod than ringed seals, and the larger cod were distributed in deeper water than smaller cod. Thus it appears that the 2 seal species exploit different fractions of the same resource.
\end{abstract}

KEY WORDS: Ringed seal · Harp seal · Diet · Prey preference $\cdot$ Niche overlap $\cdot$ Barents Sea

\section{INTRODUCTION}

The ringed seal Phoca hispida is found throughout the circumpolar Arctic, and is usually closely associated with sea ice. The global population of this species may be as large as 4 million animals (Reeves 1998). In the Barents Sea (Fig. 1), ringed seals occupy ice-covered areas that vary seasonally, being most extensive during the winter and receding northward during the spring (Belikov \& Boltunov 1998). During the summer and autumn, ringed seals are most numerous along the ice edge in the northern and eastern parts of the Barents Sea, as well as deeper into the pack-ice. Harp seals $P$. groenlandica are also an abundant northern pinniped that probably number more than 6 million animals globally. This species migrates on an annual

\footnotetext{
•Corresponding author. E-mail: lydersen@npolar.no
}

cycle, spending the summer months at the highest northern parts of their range. Many of the harp seals that breed in the White Sea use the ice edge in the Barents Sea as a feeding ground during summer and autumn (Haug et al. 1994).

Several studies have been conducted on the diet of ringed and harp seals in the Barents Sea and adjacent waters (Gjertz \& Lydersen 1986, Lydersen et al. 1989, 1991, Weslawski et al. 1994, Nilssen 1995, Wathne 1997, Lindstrøm et al. 1998). The general finding when specimens of these 2 seal species are collected along the ice edge is that polar cod Boreogadus saida is the most important prey species, followed by different invertebrates, mainly the amphipod Themisto libellula and krill of the Thysanoessa spp.

Since there is an overlap in distribution for parts of the year for ringed and harp seals and also an apparent overlap in their diet, the potential for resource competition between these 2 seal species is great. The pur- 


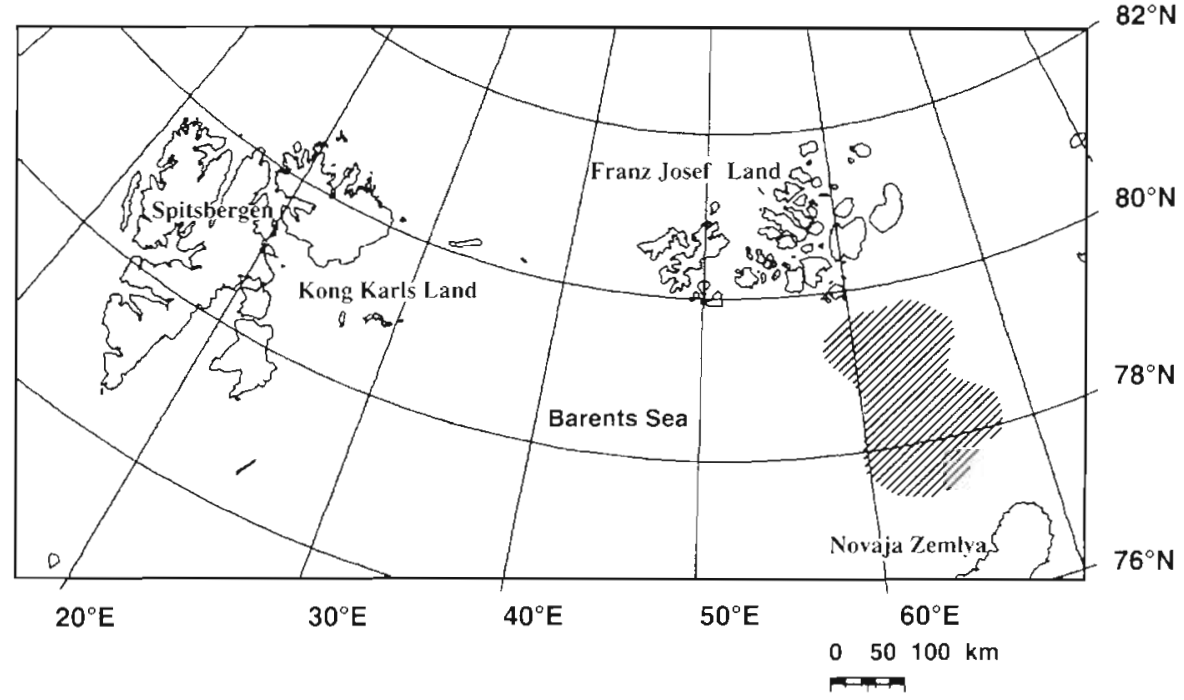

Fig. 1. Sampling area (hatched) for ringed and harp seals in the northeastern Barents Sea October 1995

pose of this study was therefore to describe the food available for ringed and harp seals in the area, and to compare this food with the gut contents in collected specimens. This would enable us to study whether the 2 species showed any particular preference for different prey organisms, and to evaluate the degree to which the feeding niches of ringed and harp seals overlapped.

\section{MATERIAL AND METHODS}

Twenty-seven ringed seals and 18 harp seals were collected along the ice edge in the northeastern Barents Sea during 18 to 28 October 1995 (Fig. 1). The seals were shot using high-powered rifles (Cal 30-06 and 308) while they were hauled out on ice floes. Seals which had been shot were immediately brought aboard the research vessel, where the stomachs and intestines were extracted, and the lower jaw was collected in order to use teeth for age determination.

Whole stomachs and intestines were frozen at $-27^{\circ} \mathrm{C}$ until analysis. In the laboratory, stomachs and intestines were thawed and their contents were washed through 2 sorting sieves with mesh size 2.0 and $0.5 \mathrm{~mm}$, respectively. The sieved contents were then stored in vials with $96 \%$ ethanol. During a second stage of analysis the contents were divided into fish and invertebrates. Fish material was identified to the lowest possible taxon by studying otoliths under a magnifying glass (Breiby 1985, Härkönen 1986). Total lengths of all otoliths were measured with a digital calliper (Mitutoyo 500). Regressions of otolith length and fish mass were used to calculate the original fish mass based on data from Härkönen (1986). Since each teleost fish contains 2 sagittal otoliths, the number of fish ingested was estimated to be half of the total number of otoliths found in the stomachs and intestines.

The invertebrate fraction of the sieved material. was identified to the lowest possible taxon using Enckell (1980) The number of each identified species was recorded.

The age of the seals was determined by examining incremental growth layers in the dentine of transverse sections of the lower canine teeth (Bowen et al. 1983).

To describe and quantify food organisms found in the samplus, 2 feeding indices commonly used for stomach analysis of top predators were applied to the material (Hyslop 1980, Pierce \& Boyle 1991): (1) frequency of occurrence of each prey item $\left(\mathrm{FO}_{2}\right)$

$$
F O_{1}=\left(\frac{S_{1}}{S_{\mathrm{t}}}\right) \times 100
$$

where $S_{1}$ is the number of examined seals with stomach and/or intestines containing species $i$ and $S_{1}$ is the total number of seals examined; and (2) the relative frequency of occurrence by number $\left(N_{i}\right)$

$$
N_{i}=\left(\frac{n_{i}}{n_{1}}\right) \times 100
$$

where $n$ is the total number of individuals of prey category $i$ and $n_{t}$ is the total number of individuals of all prey categories in the gastrointestinal tract.

A resource survey was carried out on 23 to 24 October 1995 in the area at the same time as the seals were collected in order to identify and quantify available fish and invertebrates occupying this area. It was conducted from onboard the RV' Jan Mayen' using acoustic techniques for estimating the quantity of tish and invertebrates (Foote 1991) combined with pelagic and demersai trawl- 
ing for verification/identification of prey organisms detected during echo surveys. The survey area was $1715 \mathrm{~km}^{2}$. Acoustic measurements were obtained using a Simrad EK-500 split-beam echo sounding system. A minimum acoustic threshold of $-88 \mathrm{~dB}$ SV was applied, thus allowing for the detection of zoo-plankton. The echo integration surveys were conducted by cruising along predetermined transects in the actual areas. The allocation of acoustic values to species groups was carried out on the basis of the acoustic character of each species group in combination with trawl catches. Trawls were conducted in response to changes in the echo sounder observations. Both pelagic and demersal trawls were used to sample the observed scatters. For pelagic trawling an $18.3 \mathrm{~m}$ trawl (Harstadtrål, Norway) fitted with a Scanmar depth monitor was used. For demersal trawling a 'Super Camplin' 1800 mesh shrimp trawl with rubber bobbins was used. Both trawls were fitted with an $8 \mathrm{~mm}$ net inside the cod end in order to sample fish fry and zooplankton. The prey biomass was estimated in 4 depth strata: 0-100 m, 100-200 m, 200-300 m, and $300 \mathrm{~m}$-bottom. The partitioning of the depth strata was based mainly on the echogram scatters.

The estimated total biomass of potential prey was calculated in tonnes of prey in each $100 \mathrm{~m}$ depth stratum. To calculate the number of prey organisms in each depth stratum, the total biomass was divided by the average mass of a particular prey type obtained from specimens taken from the trawls in the same area $(n=100$ for each prey type in each stratum; randomly selected). Where numbers from more than 1 depth stratum are shown, they were calculated from summed total biomass from the strata, divided by the average mass of the prey item in question.

Manly's $\alpha$ preference index (Krebs 1989) was used to examine whether the seals were selecting particular prey types. Because the number of prey eaten by a predator is small in relation to prey availability present in the sampling area, Manly's $\alpha$ for constant prey populations was chosen. The formula for this index is:

$$
\alpha_{1}=\frac{r_{i}}{n_{i}} \times \frac{1}{\sum\left(r_{j} / n_{j}\right)}
$$

where $\alpha_{i}$ is the preference index for prey type $i_{i} r_{i}$ and $r_{j}$ are the proportion of prey type $i$ or $j$, respectively, in the diet $\left(i\right.$ and $j=1,2,3, \ldots, m$ ); $n_{i}$ and $n_{j}$ are the proportion of prey type $i$ or $j$ in the environment; and $m$ is the number of prey types available. The $\alpha$-values quantify the probability that an individual prey item is selected from a particular prey group when all prey species are equally available. Probability ranges from 0 , which means that there is no probability of selecting a given prey group, to 1 , which means that the prey group will always be selected. The prey preference estimates are based upon numbers.
To calculate niche overlap between ringed and harp seals Pianka's (1973) index was used:

$$
O_{j k}=\frac{\sum_{i=1}^{n}\left(p_{i j} \times p_{i k}\right)}{\sqrt{\sum_{i=1}^{n} p_{i j}^{2} \sum_{i=1}^{n} p_{i k}{ }^{2}}}
$$

where $O_{j k}$ is Pianka's measure of niche overlap index between predator species $j$ and species $k_{i} p_{j j}$ is the proportion of prey species $i$ in relation to the total amount of prey ingested by species $j_{i} p_{i k}$ is the proportion of prey species $i$ in relation to the total amount of prey ingested by species $k$ and $n$ is the total number of prey species

Pianka's index is symmetrical, i.e. overlap between species $j$ and species $k$ is identical to overlap between species $k$ and $j$. The index ranges from 0 , i.e. no overlap, to 1 , i.e. complete overlap. It is generally considered that values of Pianka's index $\left(O_{j k}\right)$ higher than 0.6 means that there is a biologically significant niche overlap for the resource(s) examined (Wallace 1981).

Calculation of niche overlap was based on 5 prey groups; Themisto libellula, polar cod, Liparidae spp., Thysanoessa spp. and 'other fish'. The basis for calculation of Pianka's niche overlap index was the number of prey items by group. In this analysis, conversion factors were applied to reduce over-representation of small-sized prey groups. Each prey item was given as an average 'polar cod biomass unit' $(6.0 \mathrm{~g})$, i.e. a T. libellula with an average mass of $0.291 \mathrm{~g}$ got a conversion factor of 20.6, and so on for the other prey species (see Table 5 ).

Levins' measure $(B)$ was used in order to estimate the niche breadth of the seals (Krebs 1989).

$$
B=\frac{1}{\sum_{i=1}^{n} p_{i}{ }^{2}}
$$

where $p_{i}$ is the fraction of prey item $i$ in the diet ( $\Sigma p_{1}=1.0$ ), and $n$ is the number of prey groups. This measure varies between 1 and the total number of prey groups found in the diet. If only 1 prey group is eaten, the niche breadth is 1 . The more evenly the different prey groups are consumed, the higher the niche breadth.

\section{RESULTS}

The mean age of the collected ringed seals was $2.3 \pm$ $3.5 \mathrm{yr}(\mathrm{SD})$, ranging from 0 to $10 \mathrm{yr}$. The corresponding values for the harp seals were $11.9 \pm 7.7 \mathrm{yr}$ (SD), ranging from 1 to 24 yr. All 27 ringed seals had identifiable contents in their gastrointestinal tracts. Polar cod and Themisto libellula dominated their diet, with a minor 
contribution from other fish species (Table 1). All 18 harp seals also had identifiable contents. Polar cod was also the dominant prey item for this species, followed by $T$. libellula and Liparidae spp. (Table 1).

The resource survey revealed a great abundance of pelagic crustaceans (Thysanoessa spp. and $T$. libellula), which constituted about $99 \%$ of the estimated prey biomass available in the area (Table 2). Fish constituted only about $1 \%$ of the total biomass. Polar cod were the most abundant fish $(73 \%$ of all fishes). Approximately $80 \%$ of the estimated prey biomass was distributed in the upper $200 \mathrm{~m}$, while less than $1 \%$ was below $300 \mathrm{~m}$. Although prey organisms were considerably more patchily distributed in the upper $100 \mathrm{~m}$ and below $300 \mathrm{~m}$ compared to the 2 intermediate depth layers, the species composition was relatively homogeneous in the whole survey area.

The number of specimens within each prey group taken by seals in relation to the number of specimens within each group found in the resource survey (Table 3) was the basis for calculations of the preference indices. Analyses showed that both ringed and harp seals had a clear preference for fish as prey, with polar cod being the most important (Table 4). Themisto libellula and Thyssanoessa spp. both scored zero on the preference index for both seal species, even though both species were very abundant in the study area.

For the analyses of niche overlap between ringed and harp seals, the numerical results from Table 1 were adjusted into 'polar cod units' based on the size of average specimens within each prey group (Table 5). The dominance of polar cod in the diet of both ringed and harp

Table 1 Results from analyses of gastrointestinal tract contents of ringed $(n=27)$ and harp $(n=18)$ seals collected along the ice edge in the Barents Sea in October 1995. (FO, frequency of occurrence of each prey item; $N_{i}$ : relative frequency of occurrence by number)

\begin{tabular}{|c|c|c|c|c|}
\hline \multirow{2}{*}{ Prey item } & \multicolumn{2}{|c|}{ Ringed seal } & \multicolumn{2}{|c|}{ Harp seal } \\
\hline & $F O_{1}$ & $N$ & FO, & $N_{1}$ \\
\hline Boreogadus saida & 88.9 & 53.5 & 778 & 62.3 \\
\hline Themisto libellula & 100.0 & 45.3 & 66.7 & 20.1 \\
\hline Liparidae spp & 18.5 & 01 & 44.4 & 10.7 \\
\hline Thysanoessa spp. & 11.1 & 0.0 & 11.1 & 0.1 \\
\hline Other fish species & 14.8 & 1.1 & 33.3 & 6.9 \\
\hline
\end{tabular}

seals resulted in a nearly complete niche overlap between the 2 seal species $\left(O_{k}=0.985\right)$. However, the sizes of the polar cod taken by these 2 seal species are quite different. Harp seals fed on significantly larger specimens than ringed seals (Fig. 2; Pearson chisquare, $\left.\chi^{2}=1075, p<0.001\right)$. Polar cod collected by trawling at different levels in the water column were of different size. Those found in deeper water were significantly larger than those found in shallow water (Fig. 2; Pearson chi-square, $\left.\chi^{2}=133, p<0.001\right)$. Levin's niche breadth indices for ringed seals and harp seals were found to be 2.03 and 2.25 , respectively.

\section{DISCUSSION}

The type of resource survey conducted during this study is sensitive to methodical bias caused by the mixture of zooplankton and fish in the sampling environment. Due to different fishing efficiencies of the pelagic and demersal trawls with regard to fish and zooplankton, partitioning of backscattering coefficient values between fish and zooplankton had to be made subjectively (Lindstrøm et al. 1998). In addition, sympagic prey organisms were not included in the resource survey, since methods for assessing biomass or collecting specimens from the underside of the ice were not available. Nevertheless, pelagic crustaceans 
Table 4. Prey preference by ringed and harp seals sampled in the northeastern Barents Sea in October 1995, measured by Manly's preference index $(\alpha)$

\begin{tabular}{|lcc|}
\hline Prey item & $\begin{array}{c}\text { Manly's } \alpha \text { for } \\
\text { ringed seals }\end{array}$ & $\begin{array}{c}\text { Manly's } \alpha \text { for } \\
\text { harp seals }\end{array}$ \\
\hline Boreogadus saida & 0.87 & 0.42 \\
Themisto libellula & 0.00 & 0.00 \\
Liparidae spp. & 0.01 & 0.31 \\
Thysanoessa spp. & 0.00 & 0.00 \\
Other fish species & 0.13 & 0.26 \\
\hline
\end{tabular}

heavily dominated the pelagic ecosystem during the period of investigation and the dominant species overall were Themisto Iibellula and Thyssanoessa spp. Both these invertebrates are key species in the Barents Sea ecosystem, and represent an important link between herbivorous zooplankton and fish, birds and
Table 5. Diet composition, expressed as relative frequency of occurrence as numbers of prey items of each species identified in ringed and harp seal gastrointestinal tracts, sampled in the northeastern Barents Sea in October 1995. Conversion factors compensate for size differences between specimens of different prey groups

\begin{tabular}{|lrrr|}
\hline Prey item & $\begin{array}{c}\text { Ringed } \\
\text { seal }\end{array}$ & $\begin{array}{c}\text { Harp } \\
\text { seal }\end{array}$ & $\begin{array}{c}\text { Conversion } \\
\text { factor }\end{array}$ \\
\hline Boreogadus saida & 94.37 & 79.00 & 1.00 \\
Themisto Lbellula & 3.88 & 1.23 & 20.61 \\
Liparidae sp. & 0.14 & 12.42 & 1.09 \\
Thysanoessa spp. & 0.00 & 0.00 & 19.93 \\
Other fish species & 1.61 & 7.34 & 1.20 \\
\hline
\end{tabular}

marine mammals including harp and ringed seals (Bradstreet \& Cross 1982, Lønne \& Gulliksen 1989, Lydersen et al. 1991, Sakshaug et al. 1992, Mehlum \& Gabrielsen 1993, Percy 1993, Nilssen 1995).
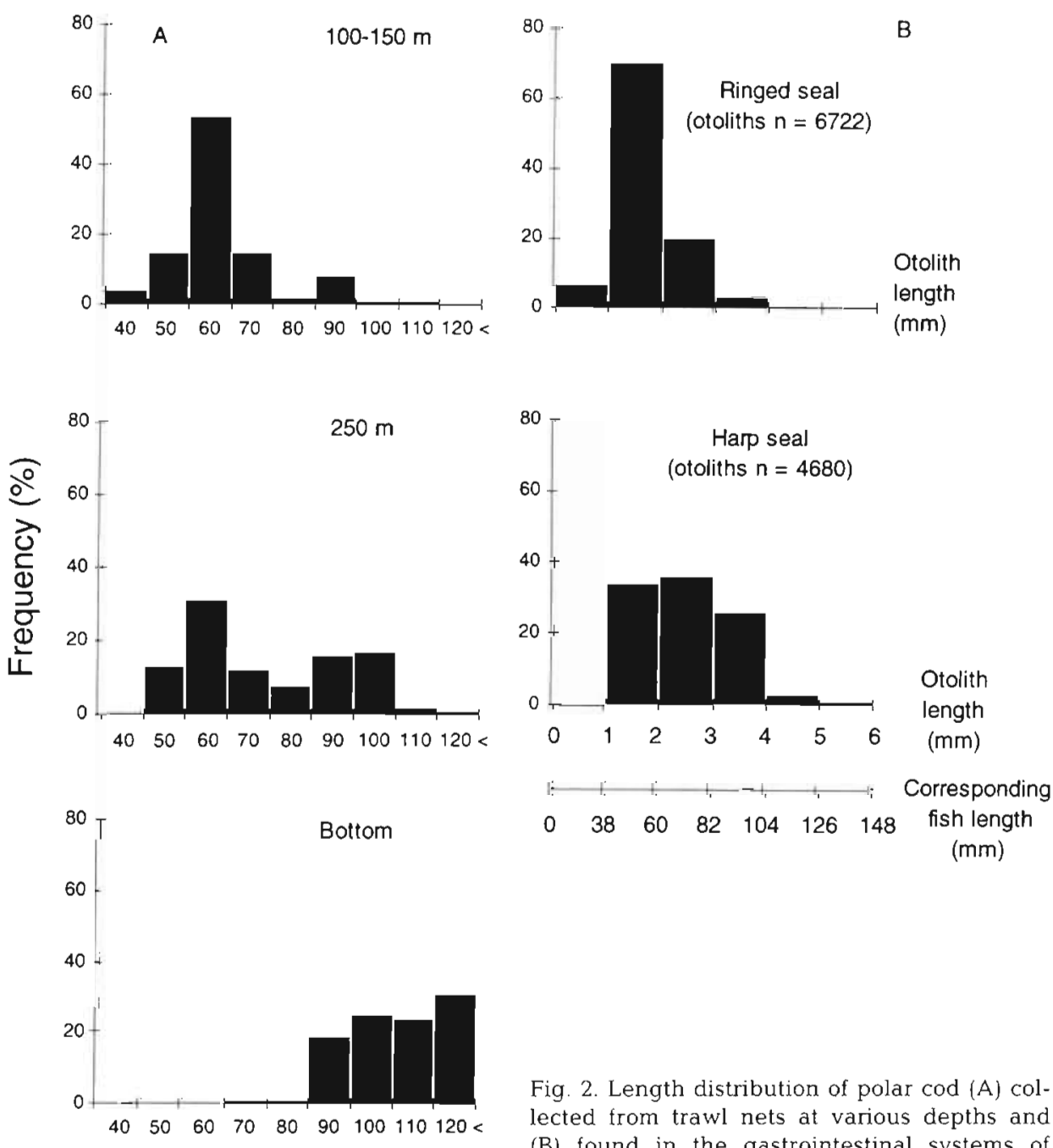

Fish length $(\mathrm{mm})$

Fig. 2. Length distribution of polar $\operatorname{cod}(\mathrm{A}) \mathrm{col}$ lected from trawl nets at various depths and (B) found in the gastrointestinal systems of ringed and harp seals 
The resource survey showed that fish species accounted for less than $2 \%$ of the biomass available as potential food for seals, and most of the fish were polar cod. Polar cod fry are found throughout much of the northern and eastern Barents Sea in autumn, especially in the upper water column $(0$ to $50 \mathrm{~m}$ ). In the spring and summer they undertake feeding migrations from the southeast to the north and west and thereby spread widely across the Barents Sea. Ecological studies conducted in Spitsbergen coastal waters found that 0-group polar cod were found in the upper echo layer (15 to $80 \mathrm{~m}$ ), while older and larger polar cod were distributed in deeper waters $(215$ to $370 \mathrm{~m}$ ) (Falk-Petersen et al. 1986). A similar age and size versus depth distribution of polar cod was also observed in the present study (see Fig. 2).

Based on the diet analysis of the seals in this study. polar cod and Themisto Iibellula were found to be the dominant prey species. This analysis was based on the relative frequency of occurrence by number, which gives relatively small prey organisms, e.g. $T$. Iibellula, a disproportionate large importance compared to larger prey. e.g. polar cod. When the preference indices were considered, polar cod dominated the diet. Thyssanoessa spp. were not eaten at all, and $T$. libellula had a preference index of zero, even though the numerical frequency of occurrence based on stomach and intestine analysis might suggest that this prey species is important. So why, in this large soup of potential prey organisms, do the seals feed on a prey species that constitutes only $1 \%$ of the total biomass available as food? Part of the explanation for this selectivity might be found in the differences in the energy content of the prey organisms. Both polar cod and $T$ libellula vary seasonally in energy content, and in the autumn polar cod represent nearly twice as much energy per mass unit as $T$ libellula $(7.0 \mathrm{MJ}$ vs $3.9 \mathrm{MJ} \mathrm{kg}^{-1}$, respectively) (Sakshaug et al. 1992). A second factor related to energetics is that the digestible energy (DE) is probably higher in polar cod than in $T$. libellula. A study measuring DE in harp seals fed capelin Mallotus villosus and $T$ libellula resulted in higher values for the fat fish than for the amphipod (94 and $81 \%$, respectively) Murtensson et al. 1994). It is therefore reasonable to assume that the relatively fatter polar cod has a higher DE than $T$ libellula when digested by the seals. From an energetic point of view, this further increases the advantages of preferring polar cod to amphipods. A third factor is the size difference between these prey types. The average mass of a T. libellula was found to be $0.291 \mathrm{~g}$, which was on average 20.6 times less than that of an average polar cod (see Table 2). If we consider the difference in energy content and DE for these 2 prey types, the seal would have to capture about 43 specimens of $T$. libellula to obtain an energy intake similar to that from a single polar cod. It is not known how these seals capture such small food objects, but if they pick them one by one, the energetic costs of prey capturing per unit of energy is probably much higher for the amphipods than for the larger fish.

Based on Pianka's index for niche overlap, the ringed seals in this study were found to almost completely overlap with that of harp seals collected in the same area $\left(O_{j k}=0.985\right)$. Because comparable studies on niche overlap in marine mammals are lacking, a niche overlap value of greater than or equal to $60 \%$ was regarded as a significant overlap, based on Wallace's (1981) study of 2 fish species in Mississippi. Accordingly we can assume that a significant niche overlap exists between ringed and harp seal diet based on analyses of their gastrointestinal tracts. Both seal species in this study show a clear preference for polar cod, and their feeding niches overlap almost $100 \%$. However, when considering the size of the polar cod preyed upon by these 2 seal species, a picture emerges that brings some nuances into this apparent $100 \%$ exploitation of the same resource. Harp seals feed on significantly larger polar cod than ringed seals. If we consider the depth distribution of different size/age classes of polar cod, we find that the smaller cod are found in the upper water masses (Falk-Petersen et al. 1986), while the larger cod are found deeper and closer to the bottom (see also Fig 2). Recently acquired data on the diving behaviour of these seal species support the separation suggested. For harp seals tracked along the ice edge in the Barents Sea $50 \%$ of all dives are between 100 and $300 \mathrm{~m}$ (Nordøy unpubl. data), while more than $90 \%$ of ringed seal dives along the autumn ice edge north of Svalbard were shallower than $100 \mathrm{~m}$ (Lydersen unpubl. data). These 2 studies were performed on adult specimens of the 2 species. The ages of the seals in the present study showed that most of the ringed seals were juveniles, while the majority of the harp seals were adults. Since juvenile seals are likely to be poorer divers than adults (Lydersen et al. 1992), the proportion of dives shallower than $100 \mathrm{~m}$ for the ringed seals in this study is probably even higher than $90 \%$. Thus it seems that the ringed seals are exploiting the upper and harp seals the lower part of the water column. By introducing space and a differentiated age/size approach on the polar cod resource into the niche overlap discussion, the overlap between these two seal species diminishes.

The difference in age distribution between these 2 species in our sample probably reflects the real age distribution of these 2 species along the ice edge in the Barents Sea al this time of the year (See Wathne 1997 . Lindstrom et al. 1998).

The niche breadth measurement expresses to what degree a predator is a generalist or a specialist. A generalist exploits various prey items regardless of species identity, while specialjsts are very species selective. 
Generalists are characterised by high values of niche breadth measurements, whereas specialists have low values of niche breadth. The relatively low niche breadth value found for both ringed (2.03) and harp (2.25) seals could indicate that they are specialists, but due to the low number of species in this pelagic food web ( $N=5)$, we should be cautious in making a generalisation concerning this finding. Studies of ringed seal diets in coastal regions in Svalbard (Gjertz \& Lydersen 1986, Lydersen et al. 1989, Weslawski et al. 1994) and from other Arctic regions (see Reeves 1998) have identified a much larger prey species diversity than that found in this study. Those studies suggested that ringed seals are generalists.

In this study we have shown that even though the ice edge areas occupied by ringed and harp seals were totally dominated by pelagic crustaceans, the seals preferred to feed on fish. Polar cod constituted only $1 \%$ of the available prey biomass, but was the preferred prey. Niche overlap calculations based on prey found in the gastrointestinal systems of ringed and harp seals showed an almost $100 \%$ overlap between these 2 predator species. However, harp seals prey on significantly larger polar cod than ringed seals, and the larger cods are distributed in deeper waters than the smaller ones. These 2 seal species therefore appear to exploit different fractions of the same resource.

Acknowledgements. We thank the crew and scientific personnel on board RV 'Jan Mayen' during collection of the material. We also thank Rob Barret and Kit Kovacs for comments on the manuscript.

\section{LITERATURE CITED}

Belikov SE, Boltunov AN (1998) The ringed seal (Phoca hispida) in the western Russian Arctic. In: Heide-Jørgensen $M P$, Lydersen $C$ (eds) Ringed seals in the north Atlantic. NAMMCO Sci Publ 1:63-82

Bowen, WD, Sergeant, DE, Øritsland, T (1983) Validation of age estimation in harp seals, Phoca groenlandica, using dental annuli. Can J Fish Aquat Sci 40:1430-1441

Bradstreet MSW, Cross WE (1982) Trophic relations at high Arctic ice edges. Arctic 35:1-12

Breiby A (1985) Otolitter fra saltvannsfisker i Nord-Norge. Tromura Naturvitenskap 53 (in Norwegian)

Enckell PH (1980) Kräftdjur. Fält fauna. Bokförlaget Signum, Lund (in Swedish)

Falk-Petersen IB, Fridvoll V, Gulliksen B, Haug T (1986) Occurrence and age/size relations of polar cod Boreogadus saida (Lepechin), in Spitsbergen coastal waters. Sarsia 71: $235-245$

Foote KG (1991) Abundance estimation of pelagic fish stocks by acoustic surveying. ICES CM 1991/B:33

Editorial responsibility: Otto Kinne (Editor), Oldendorf/Luhe, Germany
Gjertz I, Lydersen C (1986) The ringed seal (Phoca hispida) spring diet in northwestem Spitsbergen, Svalbard. Polar Res 4:53-56

Härkönen T (1986) Guide to the otoliths of bony fishes of the Northeast Atlantic. Danbiu A.ps. Biological Consultants, Hellerup

Haug T, Nilssen KT, Øien N, Potelov V (1994) Seasonal distribution of harp seals (Phoca groenlandica) in the Barents Sea. Polar Res 13:163-172

Hyslop EJ (1980) Stomach contents analysis-a review of methods and their application. J Fish Biol 17:411-429

Krebs CJ (1989) Ecological methodology, University of Columbia. Harper Collins Publishers, New York

Lindstrøm U, Harbitz A, Haug T, Nilssen KT (1998) Do harp seals Phoca groenlandica exhibit particular prey preferences? ICES J Mar Sci 55:941-953

Lonne OJ, Gulliksen B (1989) Size, age and diet of polar cod, Boreogadus saida (Lepechin 1773), in ice covered waters. Polar Biol 9:187-191

Iydersen C, Gjertz I, Weslawski JM (1989) Stomach contents of autumn-feeding marine vertebrates from Hornsund, Svalbard. Polar Rec 25:107-114

Lydersen C, Angantyr LA, Wiig Ø, Øritsland T (1991) Feeding habits of Northeast Atlantic harp seals (Phoca groenlandical along the summer ice edge of the Barents Sea. Can J Fish Aquat Sci 48:2180-2183

Lydersen C, Ryg MS, Hammill MO. O'Brien PJ (1992) Oxygen stores and aerobic dive limit of ringed seals (Phoca hispida). Can J Zool 70:458-461

Mårtensson PE, Nordey ES, Blix AS (1994) Digestibility of crustaceans and capelin in harp seals (Phoca groenlandica). Mar Mamm Sci 10:325-331

Mehlum F, Gabrielsen G (1993) The diet of high-arctic seabirds in coastal and ice-covered pelagic areas near the Svalbard archipelago. Polar Res 12:1-20

Nilssen KT (1995) Seasonal distribution, condition and feeding habits of Barents Sea harp seals (Phoca groenlandica). Dr Sci thesis, University of Tromsø

Percy JA (1993) Energy consumption and metabolism during starvation in the arctic hyperiid amphipod Themisto libellula Mandt. Polar Biol 13:549-555

Pianka ER (1973) The structure of lizard communities. Annu Rev Ecol Syst 4:53-74

Pierce GJ, Boyle PR (1991) A review of methods for diet analysis in piscivorous marine mammals. Oceanogr Mar Biol Annu Rev 29:409-486

Reeves RR (1998) Distribution, abundance and biology of ringed seals (Phoca hispida): an overview. In: HeideJørgensen MP, Lydersen C (eds) Ringed seals in the north Atlantic. NAMMCO Sci Publ 1:9-45

Sakshaug HJ, Bjørge A, Gulliksen B, Loeng H, Mehlum F (1992) Økosystem Barentshavet. Universitetsforlaget, Oslo (in Norwegian)

Wallace RK (1981) An assessment of diet-overlap indexes. Am Fish Soc 110:72-76

Wathne JA (1997) Feeding habits of ringed seals in drift ice areas in the Barents Sea. Cand Sci thesis, University of Tromse

Weslawski JM, Ryg M, Smith TG, Øritsland NA (1994) Diet of ringed seals (Phoca hispida) in a fjord of west Svalbard. Arctic 47:109-114

Submitted: December 14, 1998; Accepted: October 13, 1999 proofs received from author(s): February 21, 2000 